quences. Citing a colleague, he pointed out that "a poor man's bioterrorism weapon would be foot-and-mouth disease introduced into Texas.... The piled carcasses would no doubt feature as prominently on the nightly news as they had done during the recent outbreak in the UK."

John Hodgson, Cambridge UK He currently owns shares in PowderJect Pharmaceuticals

\title{
US legislation could boost renewable fuel and materials uses
}

Eco conomically consequential proposals in the energy bill now pending before a US House of Representatives-Senate conference committee are brightening short-term prospects for several biologically derived liquid fuels, or biofuels, and could also improve mid-term prospects for plastics and other economically valuable materials derived from similar renewable sources. Despite persistent skepticism among critics, some scientists insist that the energy yields from crops used to produce liquid fuels are positive, noting that these processes could bring dividends to biotechnology and reduce US oil imports which, in turn, could yield important political and economic benefits.

Notwithstanding cultivation, harvesting, and processing costs, producing ethanol from corn crops nets energy in a liquid, readily transported form, according to chemical engineer Bruce Dale of Michigan State University (MSU; East Lansing, MI), who spoke during a congressional briefing sponsored by the Environmental and Energy Study Institute (EESI; Washington, DC) at the end of July. And the energy produced from corn grains represents a smaller potential compared with what eventually can be derived from "cellulosic" (major structural but ordinarily discarded components of) corn and other plants, some of which may be grown on marginal lands not well suited for food crops, he says.

Dale and others discount critics, notably entomologist David Pimentel of Cornell University (Ithaca, NY), who contend that producing ethanol from corn wastes more energy than it yields. "We've been having the wrong debate about net energy values," Dale says. "The right question is whether there is net displacement of oil (petroleum) from [producing and using] ethanol, and the answer is 'yes,' about sixfold, and it will go to tenfold with cellulosic fuels."

Similar arguments are being applied to biodiesel fuels produced primarily from oils extracted from soybeans along with relatively small quantities of conventionally produced methanol, according to John Sheehan from the Department of Energy (DOE; Washington, DC) National Renewable Energy Laboratory (NREL; Golden, CO). Biodiesel fuel, which is marketed on a small scale as a $20 \%$ blend with the remainder consisting of ordinary diesel fuel, "yields 3.2 units of fuel energy for every unit of fossil fuel consumed," whereas petroleum diesel yields 0.83 units, he says, noting that its use reduces soot and bad odors, making vehicle exhaust smell more or less pleasantly, like "french fries cooking." In terms of other pollutants, biodiesel fuels tend to reduce greenhouse gas emissions, particularly carbon dioxide, but lead to increases of hydrocarbons and nitrogen oxides. "There's always a trade-off," he says.

Last year, 1.8 billion gallons of ethanol for fuel use were produced in the United States, with corn or other high-starch crops as the principal feedstocks, according to EESI. For every gallon of petroleum replaced by corn ethanol, greenhouse gas emissions are reduced by $35 \%$. Moreover, for every gallon of gasoline replaced by biomass ethanol, the greenhouse gas reduction potential is greater than $100 \%$ with the co-production of electricity, according to scientists at the DOE Argonne National Laboratory (Argonne, IL).

A federal research initiative is under way to commercialize the production of ethanol from "cellulosic" biomass, including grasses, crop residues, and wood wastes. Progress toward making better use of such biomass will come from improvements in the enzymes needed to digest cellulose and some of the other complex biopolymers that make up biomass, according to biotechnology consultant James Hettenhaus of CEA (Charlotte, NC). This "huge enzyme market" will grow substantially once those enzymes improvements are realized, he predicts. Moreover, using biomass from farm operations to generate fuels and other high-value materials could add appreciably to farmers' income.

Some of these programs are mandated in the 2002 Farm Bill that was enacted in May, including provisions that:

- Establish federal agency purchasing preference for bio-based products;

- Create a program to educate the public about the benefits of biodiesel made from vegetable oils;

- Provide financial and technical assistance to farmers, ranchers, and rural small businesses for the purchase of renewable energy systems and to make on-farm energy efficiency improvements;

- Extend and fund the Biomass Research and Development Act through 2006; and

- Establish new authorized programs to fund energy audits and renewable energy assessments and to establish biorefineries for the production of electricity, fuels, and bio-based products.

Meanwhile, a House of RepresentativesSenate conference committee deliberating over their respective versions of an Energy Bill soon could finalize provisions for a renewable fuels standard (RFS) and an ethanol "mandate." For instance, the Senate version of the proposed RFS calls for stepping up use of fuels from renewable sources to a national level of 5 billion gallons by 2012, and also would make biodiesel fuels eligible to help meet this "standard." Other provisions require the oil industry to use renewable fuels such as ethanol as they phase out use in gasoline of the oxygenating additive, methyl tertiary butyl ether (MTBE). Critics, particularly those in the fossil fuel industry, say these provisions are costly and will harm the environment. They say that MTBE does a better job of oxygenating fuels and thus of cutting pollutants and emissions than does ethanol, which makes gasoline more volatile, adding to smog and ozone levels.

Although such biofuels and legislation mandating their use are leading the current charge toward renewables, interest is also focusing on other sources of renewable energy, including crops and trees that can grow quickly on lands of poor quality; on biobased materials, including degradable plastics; and uses of such crops for bioremediation purposes. Willows are particularly versatile, according to Lawrence Abrahamson of the State University of New York at Syracuse, who spoke before the House of Representatives Energy Efficiency and Renewable Energy Caucus in July. Willows not only are a source of energy in solid form, but also are being burned as a "co-fuel" in test firings with coal, have been gasified, and are being grown and tested as a means for remediating "brown fields," in which sites are badly contaminated with pollutants, he says.

Wood pulp residues also are a promising source of renewable materials useful for producing polyhydroxy alkanoates (PHAs)-based plastics, according to Abrahamson's colleague James Nakas. He and his collaborators are using genetically engineered microorganisms to produce PHAs in high yields that can be fashioned much like petroleum-based plastics into sheets or containers that, after use, are readily biodegraded, he says: "We have the capability of producing a wide range of compounds."

Jeffrey L. Fox, Washington, DC 